$3(30) / 2015$

\author{
Malgorzata Kowalik-Olubińska \\ Uniwersytet Warmińsko-Mazurski w Olsztynie \\ malgorzata.olubinska@uwm.edu.pl
}

\title{
Jeśli nie naiwność, to co? \\ Próba rekonstrukcji idei dziecka u J.J. Rousseau
}

\section{Summary \\ If it is not naivety, then what is it? An attempt at reconstructing J.J Rousseau's idea of a child}

Categories of childlike innocence, immaturity and helplessness, which constitute the idea of a child accepted in Western societies, are regarded as obvious and undisputed. However, more and more often their obviousness is questioned by modern researchers, particularly the representatives of the new sociology of childhood, including A.W. Corsaro, A. James, C. Jenks, A. Prout, J. Qvortrup. They move away from the universal vision of an innocent child and emphasize the variety of ways of experiencing and understanding the world by children living in different social and cultural contexts. Therefore, they present the possibility to include such categories as competence and autonomy in the considerations on the construction of the image of a child. The author, assuming the above mentioned research perspective, attempts to read Rousseau's idea of a child in the context of three pairs of contradictory categories: innocence/corruption, immaturity/competence and dependence/ autonomy. Going out of the category of child innocence makes it possible to notice that children are not only victims of aggression, but sometimes they are aggressors; that they not only submit to others, but also influence what is happening to them and around them; that they are endowed with the ability to cause events and in the same time, to be innocent and helpless beings to some extent. Such findings prove that going beyond innocence in the considerations on the child's nature and examining it in the context of a wider range of categories is valid and legitimate. They also point at the ambiguity and complexity of the child's nature, which allows us to question the obviousness and universalness of the idea of a child as a being that is innocent, immature, dependent and devoid of the ability to influence events.

Słowa kluczowe: konstruowanie wizji dziecka, Rousseau, nowa socjologia dzieciństwa, dziecięca niewinność vs zepsucie, niedojrzałość vs kompetencja, zależność vs autonomia

Keywords: constructing the image of a child, Rousseau, new sociology of childhood, childlike innocence vs corruption, immaturity vs competence, dependence vs autonomy 


\section{Uwagi wstępne}

Idea dziecka jako istoty z natury dobrej, niewinnej, naiwnej i bezbronnej wydaje się być ogólnie znana i akceptowana a konstytuujące ją kategorie uznawane za oczywiste i niekwestionowalne. Oczywistość tych kategorii staje się wątpliwa w świetle poglądu, zgodnie z którym sposoby konstruowania obrazu dziecka, udzielania odpowiedzi na pytanie o to, kim jest i jakie jest dziecko, zmieniają się stosownie do czasu, miejsca i przestrzeni społeczno-kulturowej (Ariès 1960; Buliński 2007; James, James 2004; Lancy 2008; Montgomery 2009). Podważają ją konstruowane współcześnie koncepty dziecka, w których jawi się ono jako osoba zdolna do wpływania na zdarzenia, jako aktywny uczestnik i współtwórca życia społecznego. Tendencja do odchodzenia od tradycji redukowania dzieci do kategorii ludzi bezbronnych, niewinnych i pozbawionych kompetencji do autentycznego uczestnictwa w życiu społecznym ujawnia się szczególnie wyraźnie wśród reprezentantów nurtu badawczego określanego mianem nowej socjologii dzieciństwa lub społecznych badań nad dzieciństwem (Corsaro 2005; Jenks 2005; Kjørholt 2004; Prout, James 1997; Qvortrup, Corsaro, Honig 2009).

Badania podejmowane w obszarze nowej socjologii dzieciństwa ukazują możliwość wychodzenia poza dziecięcą niewinność jako zasadniczą kategorię konstytuującą ideę dziecka i konstruowania tej idei wokół takich kategorii, jak kompetencja czy autonomia. Przyjmując perspektywę badacza dzieciństwa i nawiązując do sposobu konstruowania wizji dziecka w obrębie nurtu społecznych badań nad dzieciństwem, w dalszej części prezentowanego tekstu podejmuję próbę odczytania idei dziecka u J.J. Rousseau przez pryzmat trzech par przeciwstawnych sobie kategorii: niewinności/zepsucia, niedojrzałości/kompetencji oraz zależności/autonomii. Moim zamiarem jest, z jednej strony, zarysowanie konstruowanej przez J.J. Rousseau wizji dziecka, z drugiej zaś, zaakcentowanie niejednoznaczności, złożoności i wielowymiarowości konceptu bycia dzieckiem.

\section{Dziecięca niewinność vs zepsucie}

Dziecko w ujęciu J.J. Rousseau znajduje się w tym okresie życia człowieka, w którym jest on najbliżej „stanu naturalnego”, co sprawia, że emanuje ono niewinnością, jest bezrefleksyjnie dobre i autentyczne, fizycznie słabe, ruchliwe, spontaniczne i radosne. Niewinność stanowi istotę bycia dzieckiem, atrybut dzieciństwa; kto zatem utraci niewinność, przestaje być dzieckiem (człowiekiem natury), a staje się „człowiekiem uspołecznionym” (człowiekiem człowieka), czyli dorosłym (za: Baczko 1965). Do utraty niewinności dochodzi poprzez stopniowe uleganie ludzkim namiętnościom, zatracanie się w społecznym świecie pozorów, osiąganie racjonalnej samowiedzy i zdolności do racjonalnego postrzegania świata (ibidem). Odpowiedzialnością za postępujący z czasem proces utraty niewinności obarcza Rousseau społeczeństwo, gdyż, jak stwierdza, „wszystko, wychodząc z rąk Stwórcy, jest dobre, wszystko wyrodnieje w rękach człowieka” (Rousseau 1955: 7). 
We współczesnych zachodnich społeczeństwach wyraźnie widoczne jest przywiązanie do idei niewinności dziecka. Ujawnia się ono w dyskursie publicznym ze szczególną siłą wówczas, gdy zachowania dzieci odbiegają od powszechnie akceptowanej ich wizji. Za egzemplifikację takiej sytuacji niech posłuży głośna sprawa Jamesa Bulgera - dwuletniego brytyjskiego chłopca, który został uprowadzony i zabity przez dwóch dziesięciolatków. Wywołała ona w Wielkiej Brytanii debatę publiczną o naturze dzieciństwa i kontrastujących ze sobą wizjach dziecka: Jamesa reprezentującego czystą niewinność i jego zabójców uznanych za uosobienie zła (Jenks 2005; Kehily 2008). Dostrzeżenie w sprawcach czynu samego zła, zepsucia niewinności, doprowadziło w konsekwencji do pozbawienia ich jakiegokolwiek uprzywilejowania czy tolerancji, także w świetle prawa, przysługującej zazwyczaj osobom w ich wieku. Rację należałoby zatem przyznać M.J. Kehily, która twierdzi, że w zachodnim kręgu kulturowym dzieciństwo jest nadal budowane na „niewinności seksualnej, emocjonalnej i fizycznej. Gdy zabraknie niewinności, zanika również dzieciństwo; wraz z jej utratą, niezależnie od wieku i zdolności rozumienia, dzieci stają się obiektem nacisków i trudności jak dorośli; tracą prawo do ochrony, sympatii i specjalnego orzecznictwa; przestają być dziećmi” (Kehily 2008: 40)1․

W rozważaniach nad naturą dziecka i dzieciństwa zmierza się do wskazania przyczyn stopniowego rozmywania się granic między tym, co przynależne dziecku i tym, co przynależne dorosłemu. Za jedną z istotnych przyczyn tego zjawiska uznaje się coraz łatwiejszy dostęp dzieci do nowoczesnych środków komunikowania się i przekazu informacji, który sprawia, że coraz śmielej przenikają one do zamkniętego dotychczas przed nimi świata ludzi dorosłych. N. Postman $(1983,1999)$ określa to zjawisko mianem adultyzacji dzieci i czyni go odpowiedzialnym za proces stopniowego zanikania dzieci i dzieciństwa w społeczeństwach zachodnich. Za medium, które w sposób szczególny przyczynia się do powstania i pogłębiania się tego stanu rzeczy uznaje N. Postman telewizję. Przekazuje ona bowiem ,tę samą informację każdemu w tym samym czasie, niezależnie od wieku, płci, poziomu wykształcenia czy statusu społecznego (...), sprawia, że wszystkie tajemnice dorosłych - seksualne, społeczne, fizyczne i inne - są ujawniane. (...) zmusza kulturę, by wyszła z ukrycia, usuwa wszelkie tabu" (Postman 1999: 206). Tym samym narusza ona granicę oddzielającą dzieciństwo od dorosłości². Wchodząc przedwcześnie do świata

\footnotetext{
1 Podobne do opisanego wydarzenie miało miejsce w Norwegii - dwaj sześcioletni chłopcy zabili swoją pięcioletnią koleżankę. Wzbudziło ono jednak odmienne niż w Wielkiej Brytanii reakcje społeczne. Chłopcy zostali potraktowani nie jak zabójcy, lecz jak ofiary. Uznano, że są oni w wieku, w którym nie można oczekiwać od dzieci dysponowania poziomem świadomości moralnej i rozumowania niezbędnym do analizowania sytuacji, w jakiej się znalazły. Tym, co łączy tak różne ze względu na sposób potraktowania sprawców czynu przypadki jest przyjęcie tej samej kategorii konstytuującej wizję dziecka, a mianowicie niewinności.

2 Interesująco na temat przesuwania się granic między dzieciństwem a dorosłością wypowiada się A. Aviram w kontekście analizy kondycji systemów edukacyjnych. Autor wskazuje na dwa możliwe scenariusze przemian dzieciństwa. Zgodnie z pierwszym, nadal będzie ono utożsamiane z niedojrzałością i okresem przygotowywania się do dorosłości, a jego granicę będzie wytyczać 15. rok życia. Zgodnie z drugim - po okresie wczesnego dzieciństwa granice między niedojrzałością a dojrzałością zostaną zatarte, dzieci będą zatem ujmowane jako osoby w różnym wieku, będące „w procesie poszukiwania tożsamości lub życio-
} 
spraw, problemów i przeżyć ludzi dorosłych, dziecko traci swoją niewinność i w konsekwencji przestaje być dzieckiem. U Postmana zatem, podobnie jak u Rousseau, to społeczeństwo deprawuje dzieci, umożliwiając im dostęp do realnego świata, który powinien być zastrzeżony dla osób dorosłych ${ }^{3}$.

Zasygnalizowana wyżej dwoistość postrzegania dziecka, wyrażająca się w ujmowaniu go raz jako osoby dobrej i niewinnej, innym razem jako osoby stanowiącej uosobienie zła, nie jest czymś nowym w naszym kręgu kulturowym. Wizje te konkurowały ze sobą na przestrzeni dziejów. C. Jenks (2005) określa je mianem wizji dziecka apolińskiego (niewinnego) i dziecka dionizyjskiego (demonicznego). Pierwsza przedstawia dzieci jako istoty anielskie, niewinne, nieskażone przez świat, które są wielbione i czczone przez dorosłych. Tak postrzegane dzieci „bawią się i chichoczą, uśmiechają się i śmieją zarówno spontanicznie, jak i zachęcane do tego przez dorosłych" (Jenks 2005: 65). Szczególną emanację tej idei dziecka odnajdujemy w poglądach Rousseau.

Wizja druga wyrosła z przekonania, że na dzieciach ciąży grzech pierworodny, co sprawia, że przychodzą one na świat jako „nieokiełznana siła, że są psotne i stanowią siedlisko potencjalnego zła" (Jenks 2005: 65). Konieczne jest zatem wykorzenienie zła tkwiącego w dziecięcej duszy, inaczej bowiem wrodzone skłonności dzieci mogłyby zagrozić społeczeństwu zepsuciem (Buliński 2007; James, James 2004; Schaffer 2005). Szczególną emanację tej idei odnajdujemy w purytańskiej doktrynie religijnej ${ }^{4}$. Wizja dziecka dionizyjskiego uwidocznia się również współcześnie w traktowaniu dzieci jako problemu, z którym dorośli muszą ciągle się zmagać. Dzieci są traktowane w ten sposób, ponieważ naprzykrzają się dorosłym, burzą ich spokój, wywołują zamęt w wielu sytuacjach życiowych, bardzo często zatem wprowadzają ich w stan zakłopotania i przysparzają wielu trosk ${ }^{5}$. Zachowania niektórych dzieci wywołują szczególny niepokój ze strony dorosłych, a to z tej racji, że wyraźnie naruszają one ustanowiony porządek społeczny i stwarzają zagrożenie dla społeczeństwa. Zalicza się do nich między innymi wagarowanie, zażywanie narkotyków, podejmowanie aktywności seksualnej, popełnianie wykroczeń czy dokonywanie przestępstw. Uważa się jednocześnie, że tego rodzaju zachowania i konsekwencje z nich wynikające stanowią rezultat niedojrzałości i nieodpowiedzialności

wych zmian, bez względu na chronologię, linearność lub jakikolwiek porządek” (za: Krzywosz-Rynkiewicz 2011: 215).

3 Na marginesie warto przypomnieć, że w nurcie krytycznym badań nad dzieciństwem odchodzi się od dychotomicznego podziału ludzi na dzieci i dorosłych, stawiania wyraźnej granicy między stanem bycia dzieckiem i stanem bycia dorosłym. Zamiast określeń „dzieci” i „dorośli” stosuje się termin „młodsze/ starsze osoby ludzkie" (younger/ older human beings) (por. np. G.S. Cannella 1997). Pogląd ten, co oczywiste, pozostaje w wyraźnej opozycji zarówno do poglądów N. Postmana, jak i samego J.J. Rousseau.

${ }_{4}$ Tezę o złej naturze dzieci wykorzystywano jako argument przemawiający za koniecznością surowego ich traktowania; miało ono bowiem przyczyniać się do ocalenia dzieci przed wiecznym potępieniem. Nic zatem dziwnego, że głównym tematem w poradnikach dla rodziców w XVII i XVIII wieku było „łamanie woli dziecka" (Schaffer 2005: 43).

5 U niektórych dorosłych rodzi to potrzebę izolowania się od dzieci. Wychodzenie naprzeciw tej potrzebie skutkuje próbami wyznaczania w przestrzeni publicznej czasu, miejsc i przestrzeni wolnych od obecności dzieci. Określa się je mianem „,child-free”, ,kid-free” czy też „adult only”(por. np. Corsaro 2005). 
dzieci. Przyjęcie takiego sposobu myślenia o dzieciach prowadzi do manifestowania przez dorosłych niechęci czy nawet pogardy wobec nich (Rosier 2009; por. też.: Corsaro 2005; James, James 2004).

W czasach nam współczesnych mamy zatem do czynienia z utrzymującą się, jak pisze Ayers (za: Rosier 2009), schizofreniczną wizją dziecka, która wyraża się w ukazywaniu niektórych dzieci jako bezbronnych niewiniątek, innych zaś jako zasługujących na karę czarnych charakterów. „Traktujemy dzieciństwo jako okres niewinności i piękna, ale jednocześnie konstruujemy obraz grzechu pierworodnego i zła ukrytego w dziecięcych ciałach. Uznajemy dzieci za niewinne i niegodziwe, szlachetne i zepsute, owieczki i diabełki" (ibidem: 261).

\section{Dziecięca niedojrzałość vs kompetencja}

Uznanie niewinności i naiwności za atrybut bycia dzieckiem prowadzi do przyznania dziecku statusu osoby niedojrzałej, pozbawionej siły i kompetencji niezbędnych do radzenia sobie w życiu codziennym. „Przychodzimy na świat słabi, powiada J.J. Rousseau (1955: 9), potrzebna nam jest siła; rodzimy się pozbawieni wszystkiego, potrzebna jest nam opieka; rodzimy się bezrozumni, potrzebny jest nam rozsądek. Wszystko, czego nie posiadamy rodząc się, a co jest nam potrzebne, kiedy dorośniemy, wszystko to zdobywamy przez wychowanie".

Dziecko jawi się u J.J. Rousseau jako osoba zmierzająca ku dorosłości dzięki procesowi dojrzewania, w trakcie którego realizuje ono i doskonali budzące się w nim zaprogramowane przez naturę zdolności. Ujawniające się w trakcie tego procesu naturalne cnoty i skłonności dziecka wymagają jedynie wydobycia na zewnątrz. Wychowawca musi przy tym pamiętać, że dziecko rozwija się przez osiąganie określonych etapów w kolejności wyznaczonej przez naturę. Podejmując decyzję dotyczącą tego, czego dziecko ma się uczyć, winien on zatem uwzględniać „naturę” dziecka w kolejnych stadiach rozwoju. Głównym zadaniem wychowawcy jest ułatwianie i podtrzymywanie naturalnego rozwoju dziecka „mającego tylko jego słuchać i jemu całkowicie podlegać” (Legowicz we Wstępie do: Rousseau 1955: xxxiv). Pedagogika ma być zatem zorientowana na dziecko, a proces edukacyjny, w jakim ono uczestniczy przebiegać w zgodzie z naturalnym porządkiem rzeczy.

Ważną rolę w procesie rozwoju przypisuje J.J. Rousseau, paradoksalnie, nabywaniu przez dziecko racjonalnej samowiedzy, tej samej, którą obarcza winą za stopniową utratę dziecięcej niewinności. Wchodzenie do realnego świata, zbliżanie się do stanu bycia człowiekiem uspołecznionym, wiąże się z koniecznością nabycia przez dziecko narzędzi, które pozwolą mu na skuteczną ochronę przed namiętnościami i całkowitym zatraceniem się w świecie pozorów. Takimi narzędziami są właśnie racjonalna samowiedza i racjonalny osąd świata. Za ich zdobycie płaci jednak człowiek wysoką cenę, a jest nią stopniowe oddalanie się od niewinności dzieciństwa (za: Baczko 1965).

Obecna w poglądach J.J. Rousseau idea ujmowania rozwoju jako procesu stopniowego osiągania wyznaczonych przez naturę etapów znalazła swoje odzwierciedlenie w po- 
wstałych w XX wieku stadialnych teoriach rozwoju. Ujawniła się ona wyraźnie w pracach J. Piageta, jednego z najbardziej znaczących spadkobierców intelektualnych Rousseau. Podobieństwo między opisanymi w Emilu stadiami rozwoju poznawczego i moralnego a stadiami wyodrębnionymi przez J. Piageta jest uderzające (Koops 2012). Licznie prowadzone przez psychologów rozwojowych badania, nawiązujące w dużej mierze do tradycji Piagetowskiej, przyczyniły się do poszerzenia wiedzy o dziecku, jego potrzebach i zainteresowaniach, doprowadziły jednocześnie do upowszechnienia uniwersalnej wizji dziecka i jego rozwoju. Uniwersalny charakter modeli rozwojowych jest jednak współcześnie coraz częściej kwestionowany przez badaczy (por. np. Burman 1994; Donaldson 1986; Woodhead 1999, 2005), którzy zwracają uwagę zarówno na różnorodność ścieżek rozwojowych dzieci żyjących w odmiennych przestrzeniach społeczno-kulturowych (LeVine 2007; Rogoff 2003), jak i na wielokierunkowość, nielinearność, zmienność tempa, rytmu i dynamiki rozwoju w cyklu życia człowieka (por. np. Baltes, Staudinger, Lindenberger 1999). Kwestionuje się również zasadność wprowadzania do przestrzeni edukacyjnej, niezależnie od kontekstu społeczno-kulturowego, tzw. praktyki właściwej rozwojowo, której założenia i charakter wynikają wprost z uniwersalnych modeli rozwoju (Cannella 1997; Woodhead 2005).

Wywodząca się z myśli J.J. Rousseau wizja dziecka jako osoby-dorosłej-w-procesie-stawania się ściera się współcześnie z wizją dziecka jako osoby w pełni ukształtowanej. W pierwszym ujęciu dziecko jest postrzegane jako osoba biernie oczekująca na przejście do świata racjonalnych dorosłych. Punktem docelowym rozwoju czyni się właściwości wyidealizowanej osoby dorosłej uznawanej za silną, dojrzałą, inteligentną i mądrą. Dziecko, przesuwając się wraz z wiekiem po drabinie kompetencji, przechodząc od jednego do drugiego stadium rozwoju, przybliża się stopniowo do stanu bycia osobą dorosłą.

W ujęciu drugim dziecko jest traktowane jako osoba wprawdzie odmienna od dorosłego, ale obdarzona kompetencjami w zakresie oceny i rozumienia sytuacji, w jakiej się znajduje, podejmowania działania adekwatnego do posiadanego doświadczenia życiowego. Przyznaje się bowiem, że nawet małe dzieci są obdarzone kompetencjami, które są niezbędne nie tylko do zrozumienia złożoności świata społecznego, ale także do radzenia sobie z trudnościami i problemami, jakie niesie codzienne życie. Dziecięca kompetencja, jak się sądzi, zależy przede wszystkim od kontekstu społecznego, natury problemu, doświadczenia dziecka i zakresu wsparcia, jakie otrzymuje od innych osób (Alderson 2010; Alderson, Goodwin 1993). Istotną rolę w uzyskiwaniu przez dzieci wglądu w aktualną sytuację odgrywa wywodząca się z ich własnego doświadczenia wiedza osobista. Jeśli jednak bardziej ceni się „profesjonalną wiedzę podręcznikową”, a ignoruje „mądrość” wiedzy osobistej, to wówczas łatwo jest uznać dziecko za ignoranta i osobę niekompetentną (Alderson, Goodwin 1993: 305). Kompetencję można zatem uznać za właściwość, która przynależy wszystkim istotom ludzkim, młodszym i starszym, a jej zakres zależy od doświadczenia indywidualnego, okoliczności i kontekstu społecznego, w jakim one działają (Cannella 1997). 


\section{Dziecięca zależność vs autonomia}

Przyjęcie założenia o dziecięcej niewinności, niedojrzałości, szczególnej wrażliwości i bezbronności prowadzi do przypisania dziecku statusu osoby pozbawionej autonomii, która z tej racji wymaga stałej opieki i troski ze strony dorosłych. „Rozpatrując dzieciństwo samo w sobie, pisze J.J. Rousseau (1955: 78), nie znajdziemy istoty słabszej, biedniejszej, bardziej zdanej na łaskę wszystkiego, co je otacza, istoty, która by bardziej potrzebowała litości, starań, obrony”. Istnieją przy tym „dwa rodzaje zależności - zależność od rzeczy, która pochodzi od przyrody, i zależność od ludzi, która pochodzi od społeczeństwa" (ibidem). Dziecko jest swobodne w swoim działaniu, ale zależne od natury, to ona bowiem wyznacza granice jego możliwości rozwojowych. Dorosły ma zatem chronić dziecko przed swawolą, wytwarzaniem niezgodnych z naturą przyzwyczajeń i potrzeb urojonych, przed odchodzeniem od stanu naturalnego.

Jednocześnie J.J. Rousseau (1955: 78) stwierdza: „Zależność od rzeczy, jako znajdująca się poza sferą moralności, nie sprzeciwia się wolności i nie wyklucza występków; zależność od ludzi (...) wytwarza wszelkie występki (...)”. Dorosły winien zatem jak najdłużej chronić dziecko przed wpływem wartości cywilizacyjnych, racjonalną samowiedzą, wpajaniem norm i wartości moralnych. „Utrzymuj dziecko w zależności od rzeczy jedynie, a będziesz posłuszny rozkazowi przyrody w rozwoju jego wychowania" (ibidem). Ochronie tej ma służyć między innymi izolacja dzieci poniżej dwunastego roku życia od wiedzy zawartej w książkach, wiedzy mocno zakorzenionej przecież w świecie kultury. Zamiast czerpania wiedzy z książek J.J. Rousseau proponuje, by dzieci budowały własną wiedzę o świecie na bazie bezpośrednich kontaktów z otoczeniem.

Dziecko może swobodnie działać, jednak nie w realnym świecie, bo ten przecież stanowi źródło zepsucia i zniewolenia człowieka, lecz w izolacji od niego, w przestrzeni tworzonej przez wychowawcę. Jest więc ono zależne nie tylko od natury, ale także od wychowawcy, który chroni je przed szkodliwymi wpływami świata zewnętrznego. Dziecko wiedzie zatem swoje życie obok społeczeństwa. Wbrew zapewnieniom J.J. Rousseau, że Emil jest potencjalnie zdolny do skutecznego działania w świecie zewnętrznym, do zajęcia wszystkich miejsc znajdujących się poza przestrzenią relacji z wychowawcą, jest on „,skazany na życie samotne, do którego jest też najlepiej przygotowany” (Waśkiewicz 2007: 62).

Idea utożsamiania dziecięcości z pozostawaniem w stanie zależności od dorosłych i brakiem możliwości czynnego udziału w życiu społecznym znajduje swój współczesny wyraz w dążeniu dorosłych do ochrony dziecka przed rozlicznymi zagrożeniami, jakie niesie ze sobą codzienne życie. Dążenie to wywodzi się z niepokoju dorosłych o bezpieczeństwo wrażliwych i podatnych na doznawanie krzywdy dzieci. Uczucie to sprawia, że ochrona dzieci staje się przedmiotem ciągłej uwagi i troski ze strony dorosłych. Niepokój o dzieci i lęk przed ich potencjalną wiktymizacją wynika, z jednej strony, z zakorzenionego w świadomości społecznej stereotypu naiwnego dziecka, który wyolbrzymia dziecięcą niewinność i niekompetencję, $\mathrm{z}$ drugiej zaś, z kreowaniem przez środki masowego 
przekazu pełnego niebezpieczeństw obrazu świata oraz eksponowaniem i nagłaśnianiem przypadków zdarzeń, w których ofiarami padają dzieci (Rosier 2009).

Dążenie do ochrony dzieci i powiązana z nim niechęć dorosłych wobec powiększania przestrzeni aktywnego udziału dzieci w życiu społecznym wynika częściowo również z obaw dorosłych związanych z możliwym naruszeniem przez dzieci autorytetu przypisywanego dorosłym, $\mathrm{z}$ ograniczeniem ich prawa do sprawowania władzy nad dziećmi i w związku z tym odebraniem im możliwości wpływania na dziecięce życie ${ }^{6}$. Dorośli obawiają się także, że dzieci jako osoby niedojrzałe i nieposiadające odpowiednich kompetencji będą w nieodpowiedni i nieodpowiedzialny sposób korzystały z przyznanych im praw.

W praktyce edukacyjnej sygnalizowane wyżej dążenie wyraża się nie tylko w cenzurowaniu kontaktów dzieci z realnym światem, ale także w unikaniu podejmowania z dziećmi wspólnego namysłu nad różnorodnymi problemami, jakie ujawniają się na co dzień w życiu społecznym. Ochrona dzieci przekształca się coraz bardziej w nadzór, inwigilację i kontrolę, prowadzi do znacznego ograniczenia prawa dzieci do społecznej partycypacji, do zabierania głosu w sprawach, które je dotyczą zarówno w szkole, jak i w środowisku pozaszkolnym. Rysuje się zatem wyraźnie tendencja do ograniczania przestrzeni, w obrębie której dzieci mogą być czynne i dzięki temu wypróbowywać i doskonalić własne możliwości, uczyć się życia, doświadczając różnych jego aspektów. Współcześni dorośli wydają się zatem podzielać przekonanie J.J. Rousseau o tym, że można przygotować dziecko do prawdziwego życia mimo braku możliwości bezpośredniego uczestnictwa w nim, mimo funkcjonowania obok czy na obrzeżu zasadniczego nurtu życia społecznego.

Wizji dziecka bezbronnego, niekompetentnego i wymagającego ciągłej troski ze strony osób dorosłych przeciwstawia się wizję dziecka sprawczego. Jawi się tu ono jako aktor społeczny, współtwórca własnego rozwoju i przestrzeni społeczno-kulturowych, w których żyje, jako osoba zdolna do wpływania na to, co dzieje się z nią i wokół niej (Prout, James 1997). Na przestrzeni ostatnich kilku dekad badacze dokumentowali dziecięcą sprawczość ujawnianą zarówno przez pojedyncze dzieci, jak i grupy dzieci w wielu sytuacjach. Istnieje wiele egzemplifikacji dziecięcej siły, zaradności, kompetencji i sprawczości. Można tu przywołać obrazy dzieci egzystujących w warunkach skrajnego ubóstwa, w których ukazują się nie tylko jako osoby bezradne, zdające się na opiekę innych ludzi, ale także zdolne do samodzielnego stawiania czoła trudom codzienności, dbania zarówno o siebie, jaki i o innych (rodziców, kolegów, przyjaciół) (Mizen, Ofosu-Kusi 2010). Za egzemplifikację dziecięcej kompetencji, świadomości swojej sytuacji życiowej i dążenia do bycia sprawcami zdarzeń niech posłuży fakt sporządzenia przez zgromadzenie pracujących dzieci listy postulatów dotyczących warunków ich życia i pracy. Postulaty te zostały przygotowane i ogłoszone na międzynarodowym spotkaniu zorganizowanym

\footnotetext{
${ }_{6}$ Zdaniem reprezentantów krytycznej perspektywy w badaniach nad dzieciństwem podporządkowana pozycja, jaką zajmują dzieci w społeczeństwie wynika z dychotomicznego podziału na dziecko i dorosłego. Skutkuje on ukrytą formą zniewolenia, stanowi narzędzie sprawowania władzy nad młodszymi istotami ludzkimi, którym odmawia się prawa do przemawiania we własnym imieniu (Cannella 1997: 37; por. też Burman 2008).
} 
w indyjskim mieście Kundapur, stąd ich nazwa: Kundapur Ten Points. Dzieci domagają się respektowania ich prawa do zabierania głosu w sprawach, które ich dotyczą, protestują przeciwko bojkotowi artykułów wytworzonych przez dzieci i wyzyskowi w miejscu pracy, domagają się szacunku dla siebie, dostępu do dobrej jakości opieki zdrowotnej oraz systemu edukacji i szkolenia zawodowego przystosowanego do rzeczywistości, w jakiej żyją (Nieuwenhuys 2009: 296).

\section{Refleksje końcowe}

Dziecko w ujęciu J.J. Rousseau jawi się jako istota naiwna, niewinna, dobra i bezbronna wobec zagrożeń cywilizacyjnych, rozwijająca się zgodnie z „naturalną koleją rzeczy”, zależna od natury, ale też od dorosłego, który czuwa nad jej „,naturalnym rozwojem” i chroni ją przed szkodliwymi wpływami społecznymi, posiadająca możliwość swobodnego działania, ale w ograniczonej przestrzeni relacji z wychowawcą, jako istota żyjąca i działająca w izolacji od prawdziwego świata społecznego. Atrybutem dziecka i dzieciństwa jest u J.J. Rousseau niewinność. Oddalenie się od niej oznacza odchodzenie od stanu natury; utrata niewinności jest zatem równoznaczna z eliminacją z konceptu bycia dzieckiem.

Taka wizja dziecka wydaje się być mocno zakorzeniona w świadomości współczesnych społeczeństw Zachodu. Dzieci w dalszym ciągu postrzegane są bowiem jako „,wdzięczne stworzonka" (Holt 1992), istoty nieporadne, wzbudzające swą nieporadnością uczucia tkliwości i sentymentalizmu u dorosłych. „Jesteśmy skłonni, by myśleć, że dzieci są najbardziej »wdzięczne«, gdy otwarcie wyrażają swoją niekompetencję i ignorancję. Cenimy sobie ich zależność i bezradność. (...). Dzieci, które rzeczywiście działają kompetentnie i inteligentnie zazwyczaj nie robią na nas wrażenia »wdzięcznych«" (Holt 1992: 82). Przywiązanie do takiego sposobu postrzegania dziecka świadczyć może, z jednej strony, o dużej nośności idei J.J. Rousseau, z drugiej zaś, o znaczącej sile oddziaływania jego intelektualnych spadkobierców. Wyidealizowany obraz niewinnego dziecka zderza się jednak ze sposobami funkcjonowania dzieci w realiach codziennego życia. Analiza dziecięcych doświadczeń, ujawniając rzeczywiste sposoby egzystowania dzieci, dowodzi, że życie wielu z nich nie ma nic wspólnego z przebywaniem „,w mitycznym ogrodzie Szczęśliwego, Bezpiecznego, Chronionego i Niewinnego Dzieciństwa” (Holt 1975: 22-23).

Badacze reprezentujący nurt nowej socjologii dzieciństwa, wskazując na wielość sposobów przeżywania i rozumienia świata oraz radzenia sobie z codziennością przez dzieci żyjące w różnych kontekstach społeczno-kulturowych, przekonują o zasadności odchodzenia od uniwersalnej wizji niewinnego dziecka. Tym samym ukazują oni możliwość włączania do konceptualizacji dziecka takich kategorii, jak kompetencja czy autonomia. Z ideą dziecka konstruowaną przez J.J. Rousseau zderzają się wyraźnie współczesne jego koncepty, z których wyłania się osoba kompetentna, bogata w potencjał, mocna, silna, znająca, jak pisze L. Malaguzzi (za: Dahlberg, Moss, Pence 2013: 106), sto języków, radząca sobie z ,wieloma możliwościami i sposobami ich ekspresji, które się wzajemnie napędzają", obdarzona zdolnościami sprawczymi. 
Liczne badania prowadzone nad problematyką dzieciństwa w ciągu ostatnich kilku dziesięcioleci dowodzą, że dzieci są nie tylko ofiarami agresji, lecz że bywają też agresorami (jak chociażby dzieci żołnierze, por. np. Rosen 2007), nie tylko podporządkowują się innym, ale wpływają także na to, co dzieje się z nimi i wokół nich (niekiedy wręcz stają się czynnikami zmiany politycznej i kulturowej, por. np. Acharya 2010; Bluebond-Langner, Korbin 2007; Shier 2010; Shier et al. 2014), że są obdarzone zdolnością do bycia sprawcami zdarzeń i jednocześnie, do pewnego stopnia, istotami bezradnymi i bezbronnymi. „Atrybuty te manifestują się w różnych czasach i miejscach oraz w określonych okolicznościach i warunkach społecznych, politycznych, ekonomicznych i moralnych" (Bluebond-Langner, Korbin 2007: 242). Tego rodzaju konstatacje dowodzą zasadności wychodzenia w rozważaniach nad naturą dziecka poza niewinność i rozpatrywania jej w kontekście szerszego zakresu kategorii. Wskazują one także na niejednoznaczność i złożoność natury dziecka ${ }^{7}$, pozwalają więc na zakwestionowanie oczywistości i uniwersalności idei dziecka jako istoty niewinnej, niedojrzałej, zależnej i pozbawionej możliwości wpływania na zdarzenia. W kontekście tych rozważań rację należałoby zatem przyznać J. Korczakowi głoszącemu tezę, zgodnie z którą „nie ma dzieci - są ludzie” oraz współczesnym badaczom takim, jak G.S. Cannella, nawołującym do porzucenia podziału ludzi na dzieci i dorosłych i pozostania przy kategorii istot ludzkich - starszych i młodszych.

\section{Literatura}

Acharya (2010), Child reporters as agents of change. In: B. Percy-Smith, N. Thomas (eds.), A Handbook of Children and Young People's Participation. Perspectives from Theory and Practice. London and New York, Routledge.

Alderson P., Goodwin M. (1993), Contradictions within Concepts of Children's Competence. "International Journal of Children's Rights", 1.

Ariès Ph. (1995), Historia dzieciństwa. Dziecko i rodzina w dawnych czasach. Tłum. M. Ochab. Gdańsk, Marabut.

Baltes P.B., Staudinger U.M., Lindenberger U. (1999), LIFESPAN PSYCHOLOGY: Theory and Application to Intellectual Functioning. "Annual Review of Psychology”, 50.

Baczko B. (1965), Paradoksy russoistyczne: wstęp do dzieł wybranych J.J. Rousseau. Nadbitka. Warszawa.

Bluebond-Langner M., Korbin J.L. (2007), Challenges and Opportunities in the Anthropology of Childhoods: An Introduction to "Children, Childhoods, and Childhood Studies". "American Anthropologist”, 109 (2).

\footnotetext{
7 Argumentów przemawiających za trafnością tezy o niejednoznaczności natury dziecka/człowieka dostarczają także utwory literatury pięknej, do których bez wątpienia można zaliczyć „Władcę much” W. Goldinga. Przedstawiony w nim obraz życia grupy dzieci znajdujących się na bezludnej wyspie, budowania przez nich hierarchicznych relacji społecznych, dramatycznych i tragicznych w skutkach wydarzeń, ujawniania się instynktów i dziecięcego okrucieństwa podaje w wątpliwość J.J. Rousseau ideę czystości i niewinności natury dziecka. Zaprzecza on ponadto naturalistycznemu przekonaniu, zgodnie z którym człowiek, porzuciwszy cywilizację, staje się szczęśliwy.
} 
Buliński T. (2007), Kulturowy wymiar wychowania. Praktyki i ideologie. W: M. Dudzikowa, M. Czerepaniak-Walczak (red.), Wychowanie. Pojęcia. Procesy. Konteksty. Tom 1. Gdańsk, GWP.

Burman E. (2008), Deconstructing Developmental Psychology. Second edition. London, Routledge. Cannella G.S. (1997), Deconstructing Early Childhood Education. Social Justice and Revolution. New York, Peter Lang Publishing, Inc.

Corsaro W.A. (2005), The Sociology of Childhood. Thousand Oaks, Pine Forge Press.

Dahlberg G., Moss P., Pence A. (2013), Poza dyskursem jakości w instytucjach wczesnej edukacji. Języki oceny. Tłum. K. Gawlicz. Wrocław, Dolnośląska Szkoła Wyższa.

Donaldson M. (1986), Myślenie dzieci. Tłum. A. Hunca-Bednarska, E.M. Hunca. Warszawa, Wiedza Powszechna.

Holt J. (1975), Escape from Childhood. Harmondsworth, Penguin.

Holt J. (1992), Spojrzenie dorostych: dzieci jako “wdzięczne stworzonka”. W: K. Blusz (red.), Edukacja i wyzwolenie. Kraków, Oficyna Wydawnicza „Impuls”.

James A., James A. (2004), Constructing Childhood. Theory, Policy and Social Practice. Basingstoke, Palgrave Macmillan.

Jenks C. (2005), Childhood. Second Edition. London and New York, Routledge.

Kehily (2008), Zrozumieć dzieciństwo: wprowadzenie w kluczowe tematy i zagadnienia. W: M.J. Kehily (red.), Wprowadzenie do badań nad dzieciństwem. Tłum. ks. M. Kościelniak. Kraków, WAM.

Koops W. (2012), Jean Jacques Rousseau, modern developmental psychology, and education. "European Journal of Developmental Psychology", Supplement.

Kjørholt A.T. (2004), Childhood as a Social and Symbolic Space: Discourses on Children as Social Participants in Society. Doctoral thesis. Trondheim.

Krzywosz-Rynkiewicz B. (2011), Zanikanie dzieciństwa w ponowoczesności i jego konsekwencje edukacyjne. Rozważania wokót koncepcji A. Avirama. „Kultura i Edukacja”, 4 (83).

Lancy D.F. (2008), The Anthropology of Childhood: Cherubs, Chattel, Changelings. Cambridge, Cambridge University Press.

LeVine R.A. (2007), Ethnographic Studies of Childhood: A Historical Overview. "American Anthropologist", 109 (2).

Montgomery H. (2009), An Introduction to Childhood: Anthropological Perspectives on Children's Lives. Oxford, Blackwell.

Mizen P., Ofosu-Kusi Y. (2010), Asking, giving, receiving: friendship as survival strategy among Accra's street children. "Childhood", 17.

Nieuwenhuys O. (2009), From Child Labour to Working Children's Movement. In: Qvortrup, W.A. Corsaro, M.S. Honig (eds.), The Palgrave Handbook of Childhood Studies. London, Palgrave Macmillan.

Postman N. (1999), W stronę XVIII stulecia. Jak przeszłość może doskonalić nasza przyszłość. Tłum. R. Frąc. Warszawa, PIW.

Postman N. (1983), The Disappearing Child. "Educational Leadership", March.

Prout A., James A. (1997), A New Paradigm for the Sociology of Childhood? Provenance, Promise and Problems. In: James A., Prout A., (eds.), Constructing and Reconstructing Childhood: Contemporary Issues in the Sociological Study of Childhood. London, Falmer.

Qvortrup J., Corsaro W.A., Honig M.S. (2009), Why Social Studies of Childhood? An Introduction to the Handbook. In: J. Qvortrup, W.A. Corsaro, M.S. Honig (eds.), The Palgrave Handbook of Childhood Studies. London, Palgrave Macmillan. 
Rogoff B. (2003), The Cultural Nature of Human Development. Oxford, Oxford University Press.

Rosen D.M. (2007), Child Soldiers, Humanitarian Law, and the Globalization of Childhood. “American Anthropologist”, 109 (2).

Rosier K.B. (2009), Children as Problems, Problems of Children. In: J. Qvortrup, W.A. Corsaro, M.-S. Honig (eds.), The Palgrave Handbook of Childhood Studies. London, Palgrave Macmillan.

Rousseau J.J. (1955), Emil, czyli o wychowaniu. Do druku przygotował F. Wnorowski, wstępem i komentarzem opatrzył Jan Legowicz. Tłum. W. Husarski. Wrocław, Zakład im Ossolińskich, Wydawnictwo Polskiej Akademii Nauk.

Schaffer H.R. (2005), Psychologia dziecka. Tłum. A. Wojciechowski. Warszawa, Wydawnictwo Naukowe PWN.

Shier H. (2010), Children as Public Actors: Navigating the Tensions. "Children \& Society" 24,1.

Shier H., Hernandez Mendez M., Centeno M., Arroliga I., Gonzalez M. (2014), How Children and Young People Influence Policy-Makers: Lesson from Nicaragua. "Children \& Society", 28.

Waśkiewicz A. (2007), Emil, czyli życie obok społeczeństwa. „Etyka”, 40.

Woodhead M. (1999), Reconstructing Developmental Psychology - Some First Steps. "Children \& Society", 13.

Woodhead M. (2005), Early Childhood Development: a question of rights. "International Journal of Early Childhood", November. 